\title{
Seasonal dynamics of Culicoides (Diptera: Ceratopogonidae) biting midges, potential vectors of African horse sickness and bluetongue viruses in the Niayes area of Senegal
}

\author{
Maryam Diarra ${ }^{1,2^{*}}$, Moussa Fall ${ }^{1,5+}$, Assane G Fall', Aliou Diop ${ }^{2}$, Momar Talla Seck ${ }^{1}$, Claire Garros ${ }^{3,4}$, \\ Thomas Balenghien ${ }^{3,4}$, Xavier Allène ${ }^{3,4}$, Ignace Rakotoarivony ${ }^{3,4}$, Renaud Lancelot ${ }^{3,4}$, Iba Mall', \\ Mame Thierno Bakhoum ${ }^{1}$, Ange Michel Dosum ${ }^{1}$, Massouka Ndao ${ }^{1}$, Jérémy Bouyer ${ }^{1,3,4}$ and Hélène Guis ${ }^{3,4}$
}

\begin{abstract}
Background: The African horse sickness epizootic in Senegal in 2007 caused considerable mortality in the equine population and hence major economic losses. The vectors involved in the transmission of this arbovirus have never been studied specifically in Senegal. This first study of the spatial and temporal dynamics of the Culicoides (Diptera: Ceratopogonidae) species, potential vectors of African horse sickness in Senegal, was conducted at five sites (Mbao, Parc Hann, Niague, Pout and Thies) in the Niayes area, which was affected by the outbreak.

Methods: Two Onderstepoort light traps were used at each site for three nights of consecutive collection per month over one year to measure the apparent abundance of the Culicoides midges.

Results: In total, 224,665 specimens belonging to at least 24 different species (distributed among 11 groups of species) of the Culicoides genus were captured in 354 individual collections. Culicoides oxystoma, Culicoides kingi, Culicoides imicola, Culicoides enderleini and Culicoides nivosus were the most abundant and most frequent species at the collection sites. Peaks of abundance coincide with the rainy season in September and October.

Conclusions: In addition to C. imicola, considered a major vector for the African horse sickness virus, C. oxystoma may also be involved in the transmission of this virus in Senegal given its abundance in the vicinity of horses and its suspected competence for other arboviruses including bluetongue virus. This study depicted a site-dependent spatial variability in the dynamics of the populations of the five major species in relation to the eco-climatic conditions at each site.
\end{abstract}

Keywords: Vector-borne disease, Insect vectors, Spatial and temporal dynamics, Light traps, Culicoides oxystoma, Culicoides imicola, Africa, Arbovirus, Orbivirus, Equids

\section{Background}

Culicoides (Diptera: Ceratopogonidae) are small midges ( 1 to $3 \mathrm{~mm}$ ) presenting a huge diversity with more than 1,300 species described worldwide [1,2] of which some $96 \%$ are hematophagous. The females of some species of Culicoides are the vectors of pathogens of humans and

\footnotetext{
* Correspondence: myriem85@yahoo.fr

${ }^{\dagger}$ Equal contributors

'Institut Sénégalais de Recherches Agricoles, Laboratoire National de

l'Elevage et de Recherches Vétérinaires, Dakar, Sénégal

${ }^{2}$ Université Gaston Berger, Laboratoire d'Etudes et de Recherches en

Statistiques et Développement, Saint-Louis, Sénégal

Full list of author information is available at the end of the article
}

animals. However, the geographical distribution and pathogenicity of the disease agents transmitted to humans are limited, so the epidemiological relevance of Culicoides is primarily for animal health $[3,4]$. In addition to the African horse sickness virus (AHSV), Culicoides may also transmit bluetongue virus (BTV), epizootic haemorrhagic disease virus (EHDV), equine encephalitis virus (EEV), Akabane virus, bovine ephemeral fever virus and viruses in the Palyam group [5]. However, the two diseases with the greatest veterinary impact among these are undoubtedly bluetongue (BT) and African horse sickness (AHS). BT 
and AHS are caused by orbiviruses mainly affecting ruminants and equids respectively. The significance of these two arboviruses derives from their very broad geographical distribution, their potential for spreading rapidly and their major economic impact, all of which justify them being listed as notifiable diseases by the World Animal Health Organisation [6]. Since 1998, Europe has suffered a series of epizootic outbreaks of BTV with disastrous consequences on animal health [7-9].

BTV has been known in South Africa since at least the beginning of the 20th century [10]. Towards 1925, BTV was introduced into Senegal through infected sheep that were imported from South Africa. The disease continued its progression in the sheep sent to Richard-Toll (in Senegal) as the area was infested with the vectors [10]. Research on the epidemiological status of this disease in Senegal is limited to two studies conducted in the 1980 s stating that seroprevalence varies between 30 and 59\% among sheep and goats $[11,12]$.

The mortality rate due to AHS can reach $90 \%$ in susceptible horses [13]. This disease has been recognised for several centuries and probably originates from Africa [14]. It is thought to have been described for the first time in Senegal at the end of the 19th century [15]. The latest epizootic of AHS in Senegal occurred in 2007. It caused considerable economic losses, estimated to 0.9 billion FCFA (1.4 million euros) [16]. On a national scale, this epizootic led to an estimated mortality rate of $0.2 \%$ and morbidity rate of $0.3 \%$ in traditional horse breeding farms, and a $5.4 \%$ mortality rate in modern stud farms [16,17].

More than 30 species of Culicoides have been recorded in Senegal [18-20]. However, most entomological studies go back a long time, are limited in scope and did not specifically target the species in the vicinity of the animals whose health could potentially be impacted. Thus, it appeared necessary to update the list of the Culicoides species present in Senegal prior to assessing their epidemiological relevance. The present study aimed to describe the seasonal dynamics of the main species present in the vicinity of horses, which may be potentially involved in the transmission of AHSV in the Niayes region of Senegal.

\section{Methods}

\section{Survey sites}

The survey was conducted at five horse stables in the Niayes region in the vicinity of Dakar and Thies. The Niayes region of Senegal is a 25 - to $30-\mathrm{km}$ wide coastal band stretching over $180 \mathrm{~km}$ from Dakar to the southern tip of the Senegal River Delta. The climate is oceanic, typically warm and humid with strong, relatively constant winds. Vegetation is diversified and mainly composed of steppe and shrub savanna. Vegetation cover is generally less than 50\%, except in the tree plantations (mangoes, citrus), abundant in this area. The sites surveyed and numbers of livestock recorded are shown in Table 1. Distance between sites ranged from 10 to 53 kilometres.

Two main seasons are found in Senegal: the rainy season (July to October) and the dry season, sub-divided into the cold dry season (November to February) and the hot dry season (March to June). In the Niayes region, the average monthly temperature in July/August fluctuates around $27.5^{\circ} \mathrm{C}$ in Dakar. From November to February, the maximum temperature is below $28^{\circ} \mathrm{C}$ while the minimum temperature is $18^{\circ} \mathrm{C}$ along almost the whole coast. Moderate Harmattan wind can increase temperatures up to $31^{\circ} \mathrm{C}$ in May and June. Rainfall in the Niayes rarely exceeds $350 \mathrm{~mm} /$ year. Occult condensation (such as the condensation of mist and fog on foliage), referred to as "heug" or mango rain, not measured by standard rain gauges, often occurs during the dry season (particularly from December to February). The closeness of the ocean drives the high relative hygrometry that prevails in this region, varying from $15 \%$ to $90 \%$ depending on the season and distance from the sea. This region is characterized by shallow groundwater creating temporary ponds and the presence of particular vegetation usually found in much more humid regions classified as belonging to the Guinean eco-climatic area.

This area presents an important potential for agricultural development in general and animal production (large and small ruminants, equids, pigs and poultry) in particular. Dairy production, for instance, is particularly developed in this area. As the area is densely populated, wildlife is very scarce; in particular there are no wild antelopes or wild equids.

Table 1 Geographic coordinates of study sites and the numbers of animals identified

\begin{tabular}{|c|c|c|c|}
\hline Site & Latitude & Longitude & Animals within $1 \mathrm{~km}$ of the trap* \\
\hline Mbao & 14.7467 & -17.3327 & 32 horses, 2 poultry, 3 goats \\
\hline Parc Hann** & 14.7283 & -17.4298 & 50 horses, 30 ponies, 11 lions, 1 tiger , 3 hyena, 5 jackal , 6 antelopes, 21 crocodiles, 9 turtles, 7 pitons \\
\hline Niague & 14.8234 & -17.2499 & 4 cattle, 3 sheep, 30 horses, 1 donkey, 109 poultry, 1 dog \\
\hline Pout & 14.7665 & -17.0357 & 12 horses, 8 donkeys, 1,700 sheep, 1,580 cattle, 240 goats, 25 buffalos, 11,000 poultry and 150 ostriches \\
\hline Thies & 14.794 & -16.95 & 2 sheep, 24 horses (including 19 temporarily there to be mated), 50 poultry, 13 rabbits, 1 dog \\
\hline
\end{tabular}

*All traps were placed in the immediate vicinity of the horses.

**Parc Hann includes a riding center and a zoo. 


\section{Trapping methods}

Culicoides midge apparent abundance was monitored by collecting insects at five sites for three consecutive nights monthly over a year. At four sites, Mbao, Parc Hann, Pout and Thies, collections were done from July 2011 to June 2012. At the fifth site, Niague, collections were done from November 2011 to October 2012. At each of the five sites, two Onderstepoort light traps were placed at least $10 \mathrm{~m}$ apart. Traps were operated from before dusk to after dawn. Traps were positioned close to the horses (hung on a post or a tree in the vicinity of the animals) at a height of 1.5 to $2 \mathrm{~m}$ from the ground.

The NOAA (National Oceanic and Atmospheric Administration) data for daily rainfall were extracted for each of the 5 sites, (http://iridl.ldeo.columbia.edu/expert/SOURCES/. NOAA/.NCEP/.CPC/.FEWS/.Africa/.DAILY/.ARC2/.daily/. est_prcp/). Total monthly rainfall was calculated for each site. The MODIS (Moderate-resolution Imaging Spectroradiometer) 8-day temperature data, LSTday (Land Surface Temperature day) and LSTnight (Land Surface Temperature night), were retrieved for each site for the whole period of capture. At each site, we calculated the LST_mean between LSTday and LSTnight for the 8 days covering the days of capture.

\section{Identification of Culicoides}

All the samples were first sorted to discard other insects than Culicoides. When the volume of the catch exceeded $6 \mathrm{ml}$, sub-samples of $3 \mathrm{ml}$ of sedimented Culicoides were taken out of the overall sample in accordance with a modified Van Ark \& Meiswinkel [21] procedure. All the specimens were morphologically identified under a dissecting microscope. As no key encompassing the whole West African Culicoides species diversity exists, several dichotomous keys or species descriptions [20,22-26] were used to identify the specimens collected. Gender was also recorded.

\section{Statistical analyses}

The maximum abundance of both traps for three nights of collecting per month and per site was used for performing analyses, statistical tests and for plotting the graphs. Maximum numbers collected were preferred to mean numbers collected because the number of specimens collected in a trap can drop very quickly when local weather conditions are sub-optimal. Hence, the maximum of several consecutive light trap collections was considered as the best measure for abundance over a short time period [27].

A $\log 10(n+1)$ transformation was applied to abundance data of night catches. We then compared the transformed maxima between sites by performing a Kruskal-Wallis test [28]. All the statistical analyses were conducted using the
$\mathrm{R}$ version 2.15.2 [29]. Site mapping was performed with the Quantum GIS software (2.0.1).

\section{Results}

In the results below, we focus on the proven and potential vectors of $\mathrm{BTV}$ and/or AHSV because those were the most abundant at the trapping sites.

In total, 224,665 specimens of the Culicoides genus (181,464 females and 43,201 males) belonging to at least 24 different species (Table 2) were caught during the 354 separate light trap collections at 4 sites (Mbao, Pout, Thies and Parc Hann) from July 2011 to June 2012 and at Niague from November 2011 to October 2012. The most abundant species were C. oxystoma, C. kingi, C. imicola, C. enderleini and C. nivosus which accounted for respectively $43.3 \%$ (97,351), $34.6 \%$ (77,826), $12.5 \%$ (28,123), $4.2 \%$ $(9,379)$ and $1.4 \%(3,047)$ of the total number of specimens collected. These 5 species accounted for $90 \%$ of the total capture (Table 2).

Total monthly abundance of Culicoides was computed as the sum of all species collected during the night of maximum catch for all sites. The peak was recorded in September and October (Figure 1). The apparent abundance peaks differ between the 5 abundant species. Peak of abundance for C. oxystoma was observed in September and October, in July for C. kingi, February for C. imicola, October for C. enderleini and August for C. nivosus. Culicoides apparent abundance differs significantly $(\mathrm{p}=0.012)$ between months.

Overall, C. kingi was the most abundant species in terms of annual mean of maximum monthly abundance (695.0), followed by C. oxystoma (637.3), C. imicola (180.9), C. enderleini (68.6), C. nivosus (25.5); the mean of maximum monthly catches for the other species was less than 20 (Table 3). The species for which the mean of maximum monthly catches was highest at all sites was C. oxystoma with the exception of Niague, where it was superseded by C. kingi.

Throughout the study, the most abundant species at the trapping sites were also the most frequently collected. Taking all catches together, C. imicola was the most frequent species (98.4\%), followed by C. oxystoma (95.6\%), C. nivosus (89.0\%), C. enderleini (82.4\%), and C. kingi (76.9\%). However, these occurrences varied according to the site: the occurrence of C. imicola was $100 \%$ at Mbao, Niague and Thies while the occurrence of C. oxystoma was $100 \%$ at Niague, Parc Hann and Pout (Table 2).

The rainy season began in July and ended in October with maximum rainfall in August 2011 and August 2012. The spatial and temporal variations for the 5 predominant species (Figure 2) showed that abundance peaks for Culicoides varied according to site and species. The maximum abundance was highly significantly different 
Table 2 Numbers of Culicoides trapped in the Niayes area of Senegal

\begin{tabular}{|c|c|c|c|c|c|c|c|c|c|c|c|c|c|c|c|c|}
\hline \multirow{3}{*}{$\begin{array}{l}\text { Sites } \\
\text { Culicoides species }\end{array}$} & \multirow{2}{*}{\multicolumn{3}{|c|}{$\begin{array}{c}\text { Mbao } \\
(n=70)\end{array}$}} & \multirow{2}{*}{\multicolumn{3}{|c|}{$\begin{array}{l}\text { Niague } \\
(n=70)\end{array}$}} & \multirow{2}{*}{\multicolumn{3}{|c|}{$\begin{array}{c}\text { Parc Hann } \\
(n=70)\end{array}$}} & \multirow{2}{*}{\multicolumn{3}{|c|}{$\begin{array}{l}\text { Pout } \\
(n=72)\end{array}$}} & \multirow{2}{*}{\multicolumn{3}{|c|}{$\begin{array}{l}\text { Thies } \\
(n=72)\end{array}$}} & \multirow{3}{*}{$\begin{array}{c}\text { Total (\% of } \\
\text { total catch) } \\
(n=354)\end{array}$} \\
\hline & & & & & & & & & & & & & & & & \\
\hline & $F$ & $M$ & freq & $F$ & $M$ & freq & $\mathrm{F}$ & $M$ & freq & $F$ & $M$ & freq & $F$ & $M$ & freq & \\
\hline C. oxystoma* & 60579 & 13603 & 94.3 & 1530 & 707 & 85.7 & 10589 & 3280 & 100 & 3087 & 887 & 100 & 2284 & 805 & 94.4 & $97351(43.33$ \\
\hline C. kingi* & 9062 & 3593 & 94.3 & 51803 & 12672 & 100 & 239 & 41 & 60.0 & 209 & 6 & 55.5 & 186 & 15 & 55.5 & 77826 (34.64) \\
\hline C. imicola* & 11328 & 2769 & 100 & 9446 & 643 & 100 & 459 & 93 & 94.3 & 1301 & 256 & 97.2 & 1642 & 186 & 100 & $28123(12.52$ \\
\hline C. enderleini* & 3617 & 204 & 88.6 & 2079 & 465 & 100 & 1812 & 24 & 77.1 & 802 & 104 & 77.7 & 252 & 20 & 55.5 & $9379(4.17)$ \\
\hline C. nivosus* & 490 & 385 & 88.6 & 399 & 103 & 97.1 & 808 & 182 & 97.1 & 407 & 96 & 80.5 & 97 & 80 & 75.0 & $3047(1.36)$ \\
\hline C. austeni & 2 & - & 5.7 & 1062 & 2 & 68.6 & 664 & 2 & 68.8 & - & - & - & 11 & - & 11.1 & 1743 \\
\hline C. similis & 191 & 256 & 60.0 & 399 & 138 & 85.7 & 145 & 165 & 85.7 & 143 & 15 & 61.1 & 76 & 39 & 77.7 & 1567 \\
\hline C. moreli & 222 & 148 & 82.85 & 440 & 39 & 68.6 & 5 & 6 & 11.4 & 43 & 18 & 27.7 & 14 & 8 & 27.7 & 943 \\
\hline C. gambiae & 23 & 47 & 54.3 & 650 & 179 & 94.3 & 1 & 1 & 5.7 & 2 & 1 & 8.3 & 7 & 2 & 13.8 & 913 \\
\hline C. bolitinos & 66 & 28 & 65.7 & 204 & 15 & 80.0 & 7 & - & 11.4 & 26 & 6 & 25.0 & 307 & 15 & 69.4 & 674 \\
\hline C. distinctipennis & 126 & 71 & 65.7 & 142 & 69 & 80.0 & 101 & 61 & 82.8 & 12 & 1 & 19.4 & 2 & - & - & 585 \\
\hline C. milnei & 6 & - & 8.6 & 20 & - & 22.8 & 463 & 5 & 45.7 & - & - & - & - & - & 5.5 & 494 \\
\hline C. murphyi & 34 & 25 & 48.6 & 160 & 68 & 91.4 & 64 & 54 & 71.4 & 1 & - & 2.7 & 3 & 2 & 13.8 & 411 \\
\hline Culicoides sp. & 68 & 24 & 48.6 & 166 & 42 & 34.3 & 7 & 1 & 8.6 & 10 & 3 & 19.4 & 40 & 37 & 61.1 & 398 \\
\hline C. leucostictus & 124 & 86 & 85.7 & 12 & 27 & 42.8 & 16 & 13 & 40.0 & 56 & 21 & 44.4 & 23 & 16 & 50.0 & 394 \\
\hline C. loxodontis & 4 & 7 & 8.6 & 25 & 2 & 22.8 & 6 & 2 & 14.3 & 12 & 3 & 11.1 & 140 & 21 & 38.8 & 222 \\
\hline C. pseudopallidipennis & 6 & 28 & 22.8 & 14 & 7 & 28.6 & - & - & - & 1 & 6 & 13.8 & 52 & 28 & 52.7 & 142 \\
\hline C. miombo & 38 & 3 & 17.1 & 18 & 2 & 11.4 & - & - & - & 4 & 1 & 8.3 & 21 & - & 16.6 & 87 \\
\hline C. accraensis & 1 & - & 2.8 & 1 & - & 2.8 & 2 & - & 2.8 & - & - & - & 41 & 34 & 30.5 & 79 \\
\hline C. pycnostictus & 15 & 11 & 31.4 & 9 & 2 & 22.8 & 5 & 1 & 8.6 & 13 & 1 & 25.0 & 8 & 5 & 19.4 & 70 \\
\hline C. hortensis & - & - & - & 33 & - & 11.4 & 33 & - & 20.0 & - & - & - & - & - & - & 66 \\
\hline C. pretoriensis & 1 & 16 & 5.7 & - & - & - & - & - & - & - & - & - & 18 & 19 & 22.2 & 54 \\
\hline C. azerbajdzhanicus & - & - & - & 25 & 4 & 42.8 & - & 2 & 5.7 & 3 & - & 8.3 & 7 & 1 & 16.6 & 42 \\
\hline C. translucens & - & - & - & 2 & - & 5.7 & - & - & - & - & - & - & 16 & 12 & 13.8 & 30 \\
\hline C. dekeyseri & - & - & - & 17 & 8 & 28.6 & - & - & - & - & - & - & - & - & - & 25 \\
\hline Total & 86003 & 21304 & & 68656 & 15194 & & 15426 & 3933 & & 6132 & 1425 & & 5247 & 1345 & & 224665 \\
\hline
\end{tabular}

Numbers of Culicoides captured during the whole trapping period (all nights, $n=$ number of trap-nights) are presented by species and location ( $F=$ female, $\mathrm{M}=$ male, freq $=$ frequency, $\mathrm{n}=$ number of trap-nights). ${ }^{*} 5$ dominant species.

$\left(\mathrm{p}<10^{-3}\right)$ between sites. The differences in maximum abundance between species were also very significant $\left(\mathrm{p}<10^{-3}\right)$. Spatial variations in maximum abundance within each season (rainy season, hot dry season and cold dry season) for the 5 predominant species are shown in Figure 3. The differences in maximum abundance between seasons were statistically significant $\left(\mathrm{p}<10^{-3}\right)$. At four of the five locations (Mbao, Parc Hann, Pout and Thies), the highest maximum abundance for C. oxystoma, C. kingi and $C$. enderleini were obtained during the rainy season when the LSTmean temperatures were the highest (25 to $30^{\circ} \mathrm{C}$ ) (Figure 2). In contrast, during the cold dry season when LST_mean temperatures were the lowest $\left(<25^{\circ} \mathrm{C}\right)$, a decrease in C. oxystoma, $C$. kingi and $C$. enderleini abundance was observed at Mbao, Parc Hann, Pout and Thies (Figure 2). At Niague, a seasonal decline in the numbers of these species collected was not observed. At this location, largest numbers were collected during the hot dry season (March to June) for C. oxystoma (namely, in June see Figure 2 for more details) and C. nivosus; during the cold dry season (November to February) for C. imicola (namely, February - see Figure 2). At Pout, the abundance of C. imicola remained relatively stable, varying from 10 to 100 specimens per night all year round. It exhibited two small peaks of abundance: a peak during the rainy season and another in January. C. nivosus was highly abundant during the hot dry season (i.e., June - see Figure 3) at Mbao and Niague.

The Mondrian matrix (term and figure proposed by Meiswinkel et al. [30]) shows the results of all the 3 nights of collecting for the 12 months in (Figure 4). It also shows a spatial and temporal heterogeneity of the 5 dominant 


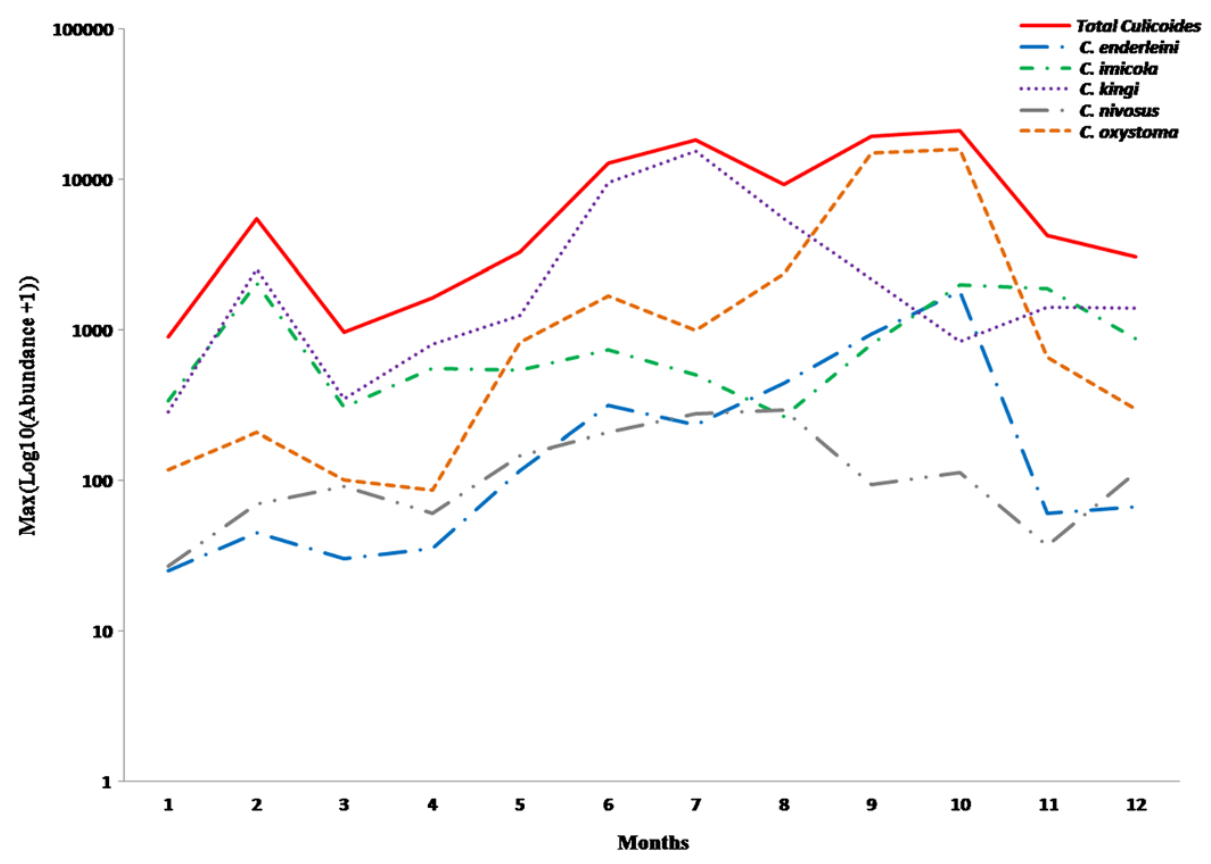

Figure 1 Seasonal variations of Culicoides abundance in the Niayes area of Senegal. Total abundance of Culicoides during the night of maximum catch is plotted on a $\log 10$ scale (in red line). For the 5 dominant species the sum of individuals caught at each site on the night of monthly maximum catch (by site and by species) are presented. Months' quotation: 1 = January to 12 = December.

species in the Niayes region. In this region, the activity of C. oxystoma, C. imicola and C. nivosus often persists all year round, with a few exceptions. C. oxystoma was absent for three consecutive nights of collecting in January at Niague, and likewise C. nivosus was absent for three consecutive nights of collecting in December at Thies. C. kingi and $C$. enderleini have longer periods of "apparent inactivity". Culicoides kingi was absent in 8 of 9 consecutive nights of collecting from February to April at Pout and Thies, in 11 of 15 consecutive nights of collecting from February to June at Mbao. Culicoides enderleini was absent in 11 of 12 consecutive nights of collecting from January to April at Thies and 3 consecutive nights of collecting in June at Mbao (Figure 4).

\section{Discussion}

Though the present study was conducted in a relatively small area of Senegal, we were able to confirm the presence of a number of Culicoides species recorded in previous surveys. Species not recorded in previous surveys in Senegal include: Culicoides austeni, Culicoides azerbajdzhanicus, Culicoides bolitinos, Culicoides hortensis, Culicoides leucostictus, Culicoides loxodontis, Culicoides milnei, Culicoides miombo, Culicoides murphyi, Culicoides pretoriensis and Culicoides translucens. Of 14 species of Culicoides collected in The Gambia by Rawlings et al. [31] with Pirbright incandescent light traps, 9 were also found in the Niayes region: Culicoides distinctipennis, C. enderleini, C. imicola, C. leucostictus,
C. milnei, C. miombo, C. nivosus, Culicoides pycnostictus and Culicoides similis. The major species shared by The Gambia and Senegal was C. enderleini and C. imicola. For these two species, the lowest abundances were observed in December and in March/April both in The Gambia [31] and the Niayes region of Senegal (our work). The largest numbers of $C$. kingi, one of the 5 most abundant species in the Niayes, were collected in July. This species was also described in Sudan with abundance peaking in February and July [32].

In the past, several cases of AHS were reported in the Niayes region. In particular, the index case of the 2007 epizootic [17] was observed here. Indeed, horse numbers have increased significantly over the last years, with the settlement of private horse farms, in addition to already established horse-breeding farms. Furthermore, many seasonal horse cart drivers leave this area to join inner Senegal before the beginning of the rainy season, for agricultural works (ploughing, transportation). These seasonal migrations might have contributed to the spread of the AHS epizootic in 2007 [17]. Moreover, Parc Hann site includes a zoo and a riding centre situated within Dakar. Numbers of Culicoides collected at this site suggest that transmission could occur even in urbanized areas.

This study shows that 4 of the 5 dominant species recorded in the Niayes region are proven or suspected biological vectors of arboviruses: C. oxystoma, C. kingi, C. enderleini and C. imicola. 
Table 3 Annual mean of maximum monthly catch in the Niayes area of Senegal

\begin{tabular}{|c|c|c|c|c|c|c|}
\hline $\begin{array}{l}\text { Sites } \\
\text { Culicoides species }\end{array}$ & $\begin{array}{c}\text { Mbao } \\
(M \pm S D)(n=70)\end{array}$ & $\begin{array}{c}\text { Niague } \\
(M \pm S D)(n=70)\end{array}$ & $\begin{array}{c}\text { Parc Hann } \\
(M \pm S D)(n=70)\end{array}$ & $\begin{array}{c}\text { Pout } \\
(M \pm S D)(n=72)\end{array}$ & $\begin{array}{c}\text { Thies } \\
(M \pm S D)(n=72)\end{array}$ & $\begin{array}{l}\text { Annual mean of } \\
\text { maximum catch }\end{array}$ \\
\hline C. kingi* & $371.8 \pm 402.5$ & $3070.3 \pm 4382.0$ & $12.0 \pm 16.9$ & $13.3 \pm 29.7$ & $7.6 \pm 13.5$ & 695.0 \\
\hline C. oxystoma* & $2221.5 \pm 4384.1$ & $106.3 \pm 148.3$ & $602.8 \pm 1528.5$ & $134.1 \pm 187.3$ & $121.9 \pm 185.6$ & 637.3 \\
\hline C. imicola* & $332.6 \pm 433.5$ & $431.4 \pm 436.9$ & $26.8 \pm 50.7$ & $49.2 \pm 35.3$ & $64.8 \pm 81.1$ & 181.0 \\
\hline C. enderleini* & $109.8 \pm 159.5$ & $106.6 \pm 146.8$ & $86.3 \pm 241.5$ & $27.1 \pm 40.2$ & $13.2 \pm 31.4$ & 68.6 \\
\hline C. nivosus* & $28.0 \pm 34.0$ & $22.1 \pm 21.2$ & $45.9 \pm 41.9$ & $24.8 \pm 25.2$ & $6.8 \pm 9.5$ & 25.5 \\
\hline C. austeni & $0.2 \pm 0.4$ & $46.9 \pm 72.7$ & $25.9 \pm 40.8$ & - & $0.7 \pm 1.4$ & 18.4 \\
\hline C. similis & $17.2 \pm 21.1$ & $20.7 \pm 20.9$ & $12.3 \pm 14.1$ & $7.7 \pm 10.2$ & $4.3 \pm 2.7$ & 12.4 \\
\hline C. gambiae & $3.0 \pm 3.7$ & $39.2 \pm 53.0$ & $0.2 \pm 0.4$ & $0.3 \pm 0.4$ & $0.5 \pm 1.1$ & 8.6 \\
\hline C. milnei & $0.3 \pm 0.6$ & $1.4 \pm 2.5$ & $18.2 \pm 37.5$ & - & - & 6.6 \\
\hline C. moreli & $10.7 \pm 11.7$ & $17.3 \pm 30.0$ & $0.3 \pm 0.8$ & $2.3 \pm 4.3$ & $0.9 \pm 1.4$ & 6.3 \\
\hline C. distinctipennis & $7.5 \pm 6.5$ & $9.1 \pm 6.5$ & $6.5 \pm 6.4$ & $0.8 \pm 1.0$ & $0.2 \pm 0.4$ & 4.8 \\
\hline C. murphyi & $2.7 \pm 2.7$ & $9.4 \pm 7.6$ & $5.3 \pm 4.1$ & $0.1 \pm 0.3$ & $0.3 \pm 0.5$ & 3.6 \\
\hline C. bolitinos & $1.9 \pm 1.8$ & $5.5 \pm 7.8$ & $0.2 \pm 0.6$ & $1.2 \pm 3.1$ & $7.4 \pm 13.8$ & 3.2 \\
\hline C. leucostictus & $6.3 \pm 6.7$ & $1.9 \pm 1.8$ & $1.3 \pm 1.3$ & $4.5 \pm 7.2$ & $1.8 \pm 1.7$ & 3.2 \\
\hline C. hortensis & - & $2.7 \pm 6.5$ & $2.3 \pm 4.9$ & - & - & 2.5 \\
\hline C. pseudopallidipennis & $2.5 \pm 4.0$ & $1.6 \pm 2.1$ & - & $0.5 \pm 0.6$ & $4.3 \pm 4.6$ & 2.2 \\
\hline C. loxodontis & $0.9 \pm 2.2$ & $1.7 \pm 2.1$ & $0.4 \pm 0.6$ & $0.8 \pm 1.8$ & $7.1 \pm 14.3$ & 2.2 \\
\hline C. dekeyseri & - & $1.7 \pm 2.4$ & - & - & - & 1.7 \\
\hline C. pretoriensis & $0.8 \pm 2.2$ & - & - & - & $1.6 \pm 3.6$ & 1.2 \\
\hline C. translucens & - & $0.2 \pm 0.4$ & - & - & $2.1 \pm 4.7$ & 1.1 \\
\hline C. miombo & $1.7 \pm 3.4$ & $1.1 \pm 2.8$ & - & $0.3 \pm 0.8$ & $1.2 \pm 2.5$ & 1.1 \\
\hline C. accraensis & $0.1 \pm 0.3$ & $0.1 \pm 0.3$ & $0.2 \pm 0.6$ & - & $3.2 \pm 5.5$ & 0.9 \\
\hline C. pycnostictus & $1.6 \pm 3.6$ & $0.7 \pm 0.8$ & $0.4 \pm 0.8$ & $0.7 \pm 0.9$ & $0.9 \pm 1.3$ & 0.9 \\
\hline C. azerbajdzhanicus & - & $1.4 \pm 1.2$ & $0.2 \pm 0.4$ & $0.2 \pm 0.4$ & $0.6 \pm 0.8$ & 0.6 \\
\hline Mean of max catches & 115.7 & 134.7 & 36.9 & 13.5 & 8.4 & 64.7 \\
\hline
\end{tabular}

The annual mean of monthly maximum abundance $(M) \pm$ standard deviation (SD) for each species during the whole trapping period are presented by location ( $n=$ number of trap-nights). The annual mean of maximum monthly abundance was the mean of the 12 maximum collections made at each site. ${ }^{*} 5$ dominant species.

The first three of these species belong to the Schultzei group [18].Culicoides oxystoma is suspected of being a BTV vector in Asia and Australasia [33], and was found infected by bovine arboviruses in Japan (Akabane, Aino, Chuzan, and D'Aguilar) [34]. Non-engorged C. kingi and C. enderleini were found infected respectively by EHDV in Sudan [35], and BTV in South Africa [36]. Although viral isolation from field-caught specimens does not prove vector competence, it shows that the species will feed on infected hosts in field conditions. Indeed, in addition to feeding on infected hosts, two other conditions are required to define a species as a vector: allowing replication and transmission of the pathogen.

At least four species of the Imicola group were found at our five sites: C. miombo, C. bolitinos, C. loxodontis, and Culicoides pseudopallidipennis. Culicoides imicola is a proven vector of BTV [13,37,38] and AHSV [13,14,39], and suspected vector of EEV [40,41] and EHDV [42].
Culicoides bolitinos is a suspected vector of BTV $[13,37,38]$, AHSV [14,39,43], EEV [40] and EHDV [42]. Lee [44] has shown that $C$. miombo is a suspected BTV vector. Furthermore, a very broad distribution of $C$. miombo has been reported in tropical and subtropical Africa, in particular in Zimbabwe, Botswana, Nigeria, Ivory Coast, The Gambia and South Africa [25].

The fifth most abundant species was C. nivosus. The abundance of this species was low in The Gambia [31] and in South Africa [45]. In the case of BTV, several studies have tested this species for its competence [46,47]; but until this date, $C$. nivosus has not been purported as a vector for BTV or AHSV. As far as we know, C. pseudopallidipennis was not incriminated of being either a BTV or AHSV vector.

Based on the major species collected, it appears essential to assess the vector competence for AHSV, the biting rate and host preferences of the species in the Schultzei 


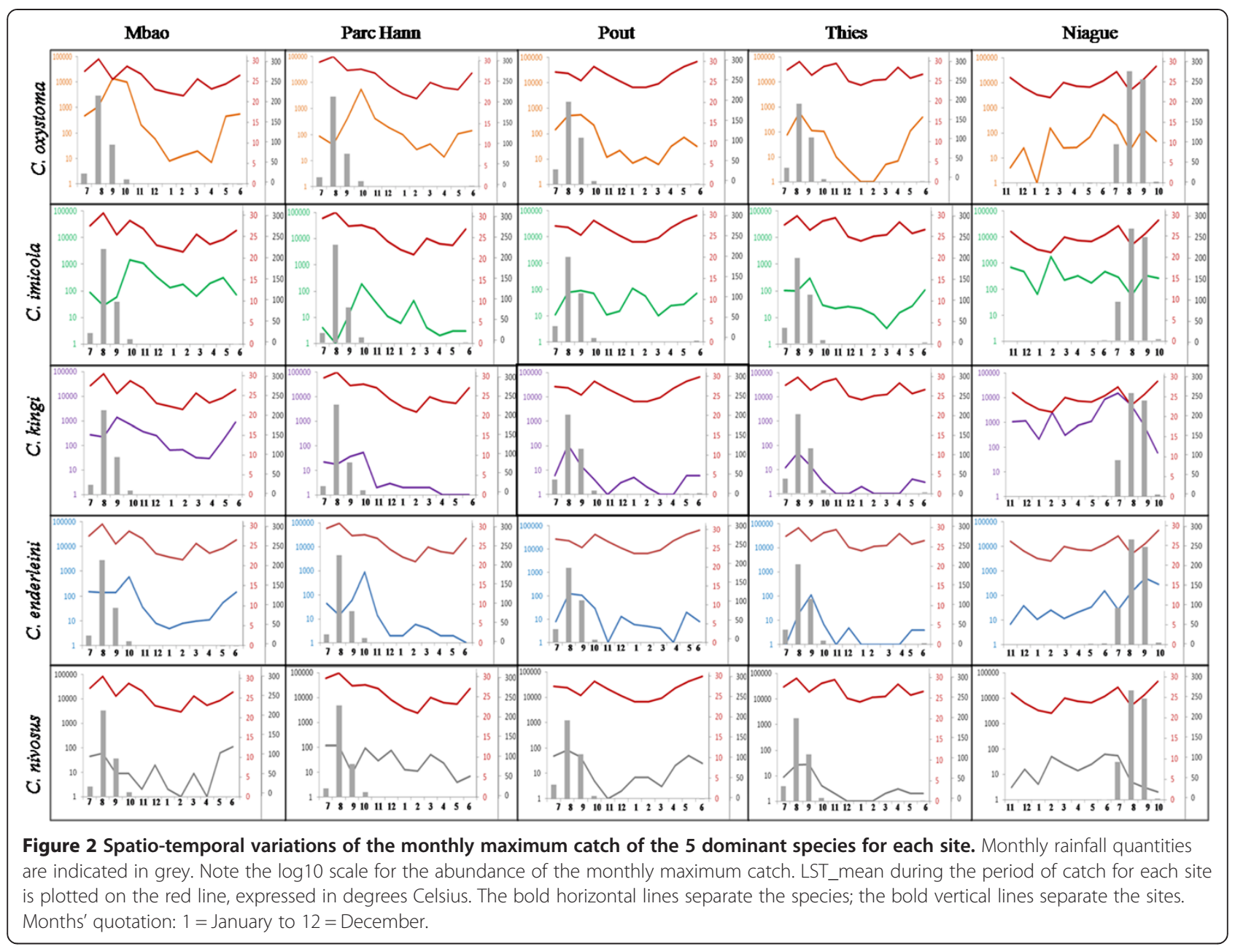

group. Indeed, in the Niayes region, depending on their competence and capacity, C. oxystoma, and/or C. kingi and/or C. enderleini may be significant vectors, perhaps more so than those in the Imicola group. In any case, evaluating the competence and capacity of all the potential vector species is crucial to better assess the risk of transmission through space and time.

The results of the present study revealed one or two peaks of abundance for the species that are potentially involved in the transmission of AHSV (C. oxystoma, $C$. imicola, C. kingi and C. enderleini). These peaks occurred from April to June, and from July to October, coinciding respectively with the emergence and spread of AHS in 2007 [17].

Previous observations showed that C. imicola was the dominant species in many sub-Saharan African countries: South Africa [48-50], Nigeria [51], Botswana [52], The Gambia [31] and Zimbabwe [53]. In Senegal, for the first time, this study shows the importance of C. oxystoma, which was the dominant species in terms of abundance at 4 of the 5 sites, and the second most abundant (behind C. kingi) at the fifth (Niague). Culicoides imicola was the second most abundant species at 4 sites and the 5th most abundant at Parc Hann. In terms of frequency of collection, C. imicola has a slight advantage over C. oxystoma.

The differences in abundance and frequency observed between sites for the 5 most abundant livestock associated species may be related to the ecological conditions that prevailed there, in particular the available larval habitats, i.e. humid locations with plenty of decaying organic matter such as animal droppings [54]. The high abundance of C. oxystoma at Mbao and Parc Hann may be connected with the presence of a permanent stream close to the Mbao riding center and a lake surrounded by marshy areas around Parc Hann [55]. The capacity of C. kingi larvae to develop in very salty muds exposed to sunlight [20] could contribute to explain why it is the most abundant species in Niague, a site close to a saltsaturated lake (Rose Lake, see Figure 2) The highest abundance for C. nivosus was observed at Mbao, perhaps in connection with the closeness of this site to the Mbao protected forest, as this species has been reported in other forested areas in Senegal (such as the Forest of 


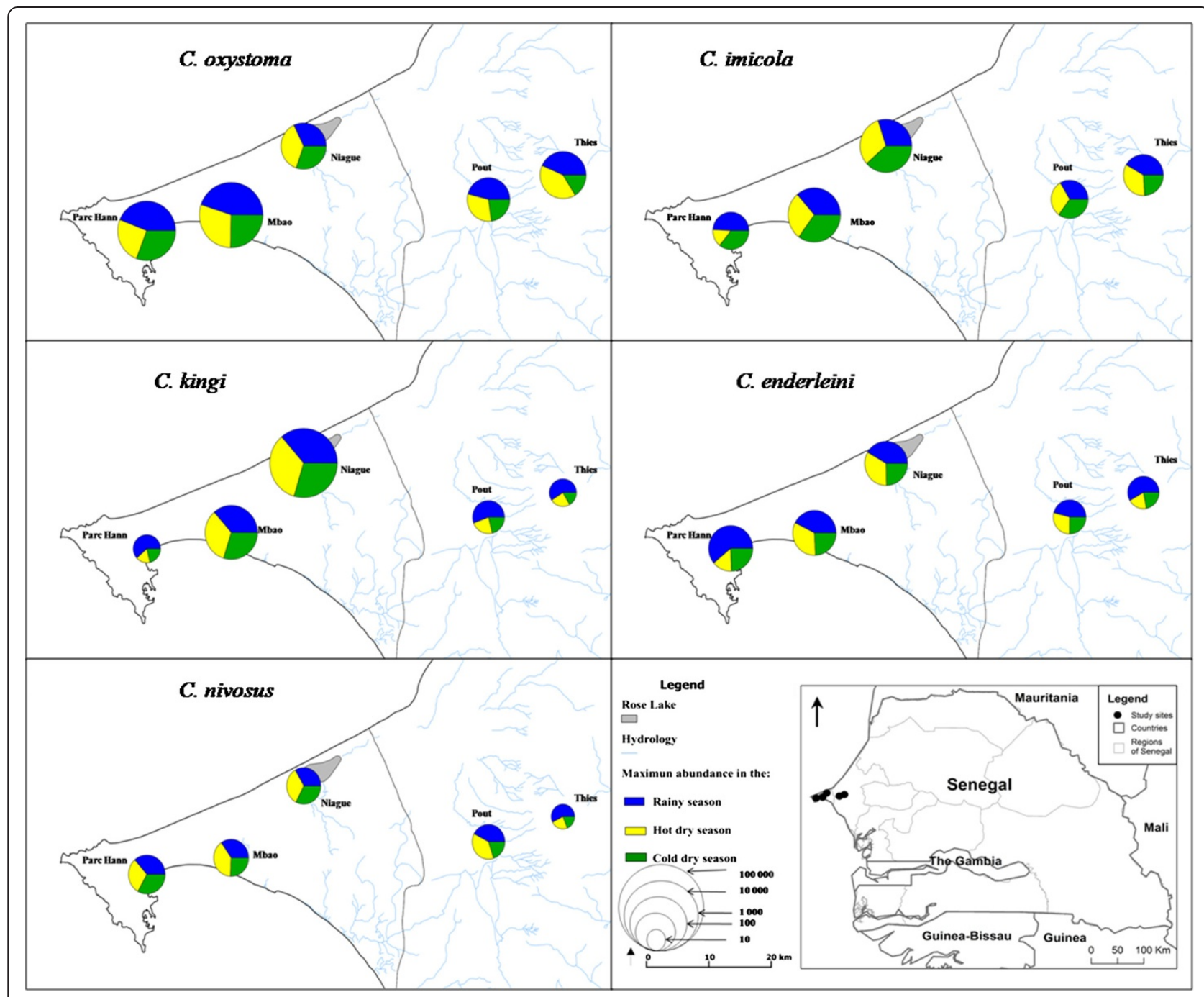

Figure $\mathbf{3}$ Spatial distribution of the $\mathbf{5}$ dominant species in the Niayes area of Senegal.

Bandia) [19]. For many species of Culicoides, larval habitats remain poorly described and larval identification techniques limited. Furthermore, although larval habitats are important determinants of the presence and abundance of Culicoides, other factors such as host characteristics (species, numbers, distance) [56,57] or trapping methods [58-60] can also greatly influence the diversity and abundance of collections made.

September and October, i.e., the end of the rainy season, were the months of highest overall abundance of Culicoides. The highest abundances of C. oxystoma were recorded during the rainy season, namely August to October. The abundances of $C$. kingi declined considerably midway through the rainy season. This is possibly due to the fact that during the tropical winter season the salt content of the large body of briny water located close to the Niague riding center might decline. Likewise, a drop in abundance during the rainy season was also observed for C. nivosus.

Culicoides catches were made in the Niayes region of Senegal, i.e. a tropical environment, it is not surprising that activity of some dominant species is observed all year round, in contrast with what is found in temperate environments such as the Netherlands for instance [30]. The fact that vector species such as C. imicola, or potential vector species such as $C$. oxystoma, are active year round contributes to increasing the risk of transmission of BTV and AHSV in these areas since the length of the transmission season is increased and no overwintering mechanisms are necessary to ensure viral transmission the following year.

Overall, it is not easy to distinguish a stable pattern over time for each species as illustrated by the spatial and temporal variability displayed on the Mondrian matrix. There 


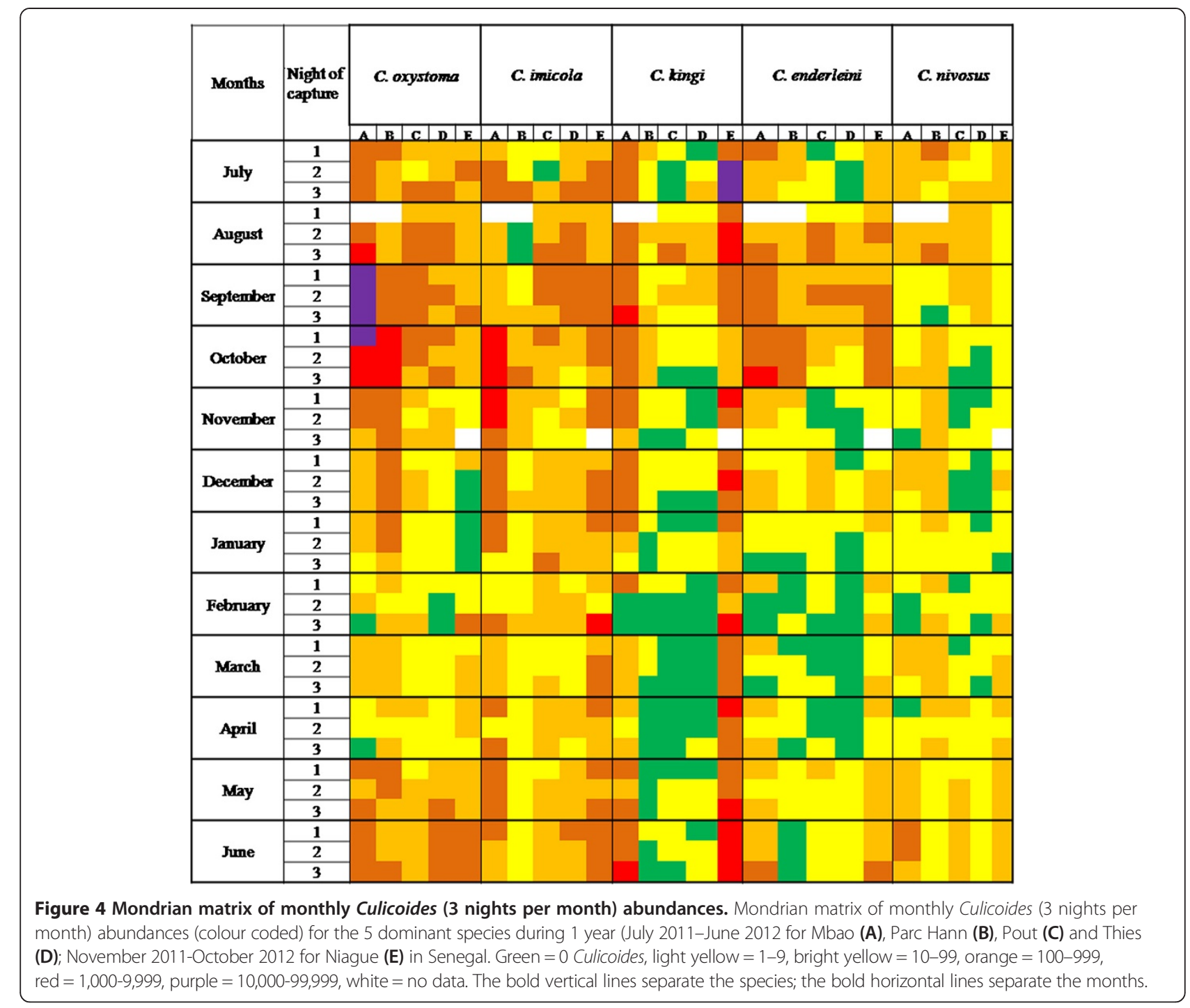

are important variations in dynamics between sites and between species: on a single site there are differences according to species, while for a single species, the pattern differs depending on the site, even for sites which are close to one another. As expected for a given site, we observed differences in patterns between species. In particular in Niague, the patterns observed for the 5 dominant species seemed to differ from those in the 4 other sites. Models need to be developed so as to better understand the influence of environmental and climatic parameters on the distribution and dynamics of Culicoides in Senegal.

\section{Conclusion}

This descriptive study of the spatio-temporal dynamics of Culicoides (Diptera: Ceratopogonidae) was able to inventory the various species present in the Niayes region in Senegal and their abundance pattern over the course of the year. Very high abundances of the species are observed mainly in September and October in this region, particularly for C. oxystoma, C. kingi, C. imicola, C. enderleini and $C$. nivosus, which are the most abundant and frequent species at the trapping sites and exhibit differing spatial patterns. The investigation showed up the presence of several species including $C$. oxystoma, which may be potential vectors for BTV and AHSV, possibly calling into question the role of C. imicola, which is thought to play as the main vector in Africa. It is essential to assess their respective competence for these two viruses so as to better evaluate the risk of African horse sickness and bluetongue disease in Senegal.

\section{Abbreviations}

AHSV: African horse sickness virus; BTV: Bluetongue virus; EEV: Equine encephalosis virus; EHDV: Epizootic haemorrhagic disease virus; LSTday: Land surface temperature day; LSTnight: Land surface temperature night;

LST_mean: Land surface temperature mean. 


\section{Competing interests}

The authors declare that they have no competing interests.

\section{Authors' contributions}

HG, AGF, MTS and JB designed and supervised the study. MF, AGF, IM performed sampling and global management of the entomological material. $\mathrm{RL}$ extracted Modis data. MF and IM performed the species identification with the help of CG, TB, XA, and IR. MTB, AMD, MD and MN participated in field and laboratory activities. MD, AGF, MTS and HG analysed the data and wrote the first draft of the manuscript. All authors revised and approved the final version of the manuscript.

\section{Acknowledgments}

The authors are particularly grateful to Jean-Claude Delécolle for his morphological training and to all people who gave assistance in operating traps on several nights (technicians, animal keepers, shepherds) in Senegal. We also thank Dr Benz and Dr D. Morley, TALA research group, Oxford University, in the frame of the European EDENext project, for providing MODIS data. This study was funded partly by the EU FP7-HEALTH-2010single-stage grant 261504 EDENext. This paper is catalogued by the EDENext Steering Committee as EDENext194 (http://www.edenext.eu). The contents of this publication are the sole responsibility of the authors and do not necessarily reflect the views of the European Commission.

\section{Author details}

${ }^{1}$ Institut Sénégalais de Recherches Agricoles, Laboratoire National de l'Elevage et de Recherches Vétérinaires, Dakar, Sénégal. Université Gaston Berger, Laboratoire d'Etudes et de Recherches en Statistiques et Développement, Saint-Louis, Sénégal. ${ }^{3}$ Cirad, UMR15 CMAEE, F-34398 Montpellier, France. ${ }^{4}$ INRA, UMR1309 CMAEE, F-34398 Montpellier, France. ${ }^{5}$ Faculté des Sciences et Techniques, Département de Biologie Animale, Université Cheikh Anta Diop, Dakar, Sénégal.

\section{Received: 26 December 2013 Accepted: 11 March 2014}

Published: 31 March 2014

\section{References}

1. Borkent A: World species of biting midges (Diptera: Ceratopogonidae). 2014 [http://wwx.inhs.illinois.edu/files/9913/9144/3328/CeratopogonidaeCatalog.pdf]

2. Borkent A: The subgeneric classification of species of Culicoides - thoughts and a warning. 2014 [http://wwx.inhs.llinois.edu/files/9613/9136/7590/ CulicoidesSubgenera.pdf]

3. Carpenter S, Groschup MH, Garros C, Felippe-Bauer ML, Purse BV: Culicoides biting midges, arboviruses and public health in Europe. Antiviral Res 2013, 100(1):102-113.

4. Linley JR, Hoch AL, Pinheiro FP: Biting midges (Diptera: Ceratopogonidae) and human health. J Med Entomol 1983, 20(4):347-364.

5. Mellor P, Baylis M, Mertens P: Bluetongue. Oxford, UK: Elsevier; 2009.

6. OIE List of diseases in force in 2006. http://www.oie.int/en/animal-healthin-the-world/oie-listed-diseases-2006/.

7. Carpenter S, Wilson A, Mellor PS: Culicoides and the emergence of bluetongue virus in northern Europe. Trends Microbiol 2009, 17(4):172-178.

8. Mellor PS, Wittmann EJ: Bluetongue Virus in the Mediterranean Basin 1998-2001. Vet J 2002, 164(1):20-37.

9. Purse BV, Mellor PS, Rogers DJ, Samuel AR, Mertens PP, Baylis M: Climate change and the recent emergence of bluetongue in Europe. Nat Rev Microbiol 2005, 3(2):171-181.

10. Curasson G: Introduction de la blue tongue en Afrique occidentale française. Bull Soc Pathol Exot 1925, 18:215-218.

11. Lefèvre $P C$, Calvez $D$ : La fièvre catarrhale du mouton (bluetongue) en Afrique intertropicale: influence des facteurs écologiques sur la prévalence de l'infection. Rev Elev Med Vet Pays Trop 1986, 39(3-4):263-268.

12. Lefèvre $P C$, Taylor WP: Situation épidémiologique de la fièvre catarrhale ovine (Blue tongue) au Sénégal. Rev Elev Med Vet Pays Trop 1983, 36(3):241-245.

13. Mellor PS, Boorman J, Baylis M: Culicoides biting midges: their role as arbovirus vectors. Annu Rev Entomol 2000, 45:307-340.

14. Mellor PS, Hamblin C: African horse sickness. Vet Res 2004, 35(4):445-466.

15. Bazarusanga $\mathrm{T}$ : Contribution à l'étude de l'épidémiosurveillance de la peste équine au Sénégal: enquêtes sérologiques dans les zones de
Rufisque, Kaffrine et Dahra. In Veterinary thesis. Université Cheikh Anta Diop de Dakar; 1995

16. Akakpo AJ, Wombou Toukam CM, Mankor A, Ly C: Impact économique de l'épizootie de peste équine de 2007 au Sénégal. Bull Anim Hlth Prod Afr 2011, 59:1-16

17. Diouf ND, Etter E, Lo MM, Lo M, Akakpo AJ: Outbreaks of African horse sickness in Senegal, and methods of control of the 2007 epidemic. Vet Rec 2013, 172(6):152.

18. Bakhoum MT, Fall M, Fall AG, Bellis GA, Gottlieb Y, Labuschagne K, Venter GJ, Diop M, Mall I, Seck MT, Allène X, Diarra M, Gardès L, Bouyer J, Delécolle JC, Balenghien T, Garros C: First Record of Culicoides oxystoma Kieffer and Diversity of Species within the Schultzei Group of Culicoides Latreille (Diptera: Ceratopogonidae) Biting Midges in Senegal. PloS One 2013, 8(12):e84316.

19. Cornet M: Les Culicoïdes (Diptera Ceratopogonidae) de l'Ouest africain (1ère note). Cah ORSTOM, sér Ent méd Parasitol 1969, VII(4):341-364.

20. Cornet MJB: Révision des espèces de Culicoides apparentées à $C$. schultzei (Enderlein, 1908) dans la région afrotropicale (Diptera, Ceratopogonidae). Bull Soc Entomol France 1994, 92(2):149-164.

21. Van Ark H, Meiswinkel R: Subsampling of large light trap catches of Culicoides (Diptera: Ceratopogonidae). Onderstepoort J Vet Res 1992, 59(3):183-189.

22. Glick Jl: Culicoides biting midges (Diptera: Ceratopogonidae) of Kenya J Med Entomol 1990, 27(2):85-195.

23. Khamala CPM, Kettle DS: The Culicoides Latreille (Diptera: Ceratopogonidae) of East Africa. TransR ent Soc Lond 1971, 123(1):1-95.

24. Meiswinkel P: Afrotropical Culicoides: a redescription of C. (Avaritia) imicola Kieffer, 1913 (Diptera: Ceratopogonidae) with description of the closely allied C. (A.) bolitinos sp. nov. reared from the dung of the African buffalo, blue wildebeest and cattle in South Africa. Onderstepoort J Vet Res 1989, 56(1):23-39.

25. Meiswinkel R: Afrotropical Culicoides: C (Avaritia) miombo sp. nov., a widespread species closely allied to C. (A.) imicola Kieffer, 1913 (Diptera: Ceratopogonidae). Onderstepoort J Vet Res 1991, 58(3):155-170.

26. Wirth WW, Hubert AA: The Culicoides of Southeast Asia (Diptera: Ceratopogonidae). Mem Am Entomol Inst 1989, 44:1-509.

27. Baylis M, el Hasnaoui H, Bouayoune H, Touti J, Mellor PS: The spatial and seasonal distribution of African horse sickness and its potential Culicoides vectors in Morocco. Med Vet Entomol 1997, 11(3):203-212.

28. Hollander M, Wolfe DA: Non parametric statistical methods. New York: Wiley; 1973.

29. R Development Core Team: R: a language and environment for statistical computing. [http://cran.r-project.org/manuals.html]

30. Meiswinkel R, Scolamacchia F, Dik M, Mudde J, Dijkstra E, VDV IJ, Elbers AR: The Mondrian matrix: Culicoides biting midge abundance and seasonal incidence during the 2006-2008 epidemic of bluetongue in the Netherlands. Med Vet Entomol 2013, 28(1):10-20.

31. Rawlings P, Snow WF, Boorman J, Denison E, Hamblin C, Mellor PS: Culicoides in relation to transmission of African horse sickness virus in The Gambia. Med Vet Entomol 1998, 12(2):155-159.

32. El Sinnary KA, Muller R, Atta el Mannan A, Hussein SH: The diurnal activity of Culicoides kingi in northern Sudan. Rev Elev Med Vet Pays Trop 1985, 38(3):270-275.

33. Mellor PS, Carpenter S, White DM: Bluetongue virus in the insect host. In Bluetongue. Edited by Mellor P, Baylis M, Mertens P. Oxford, UK: Elsevier; 2009:295-320.

34. Yanase T, Kato T, Kubo T, Yoshida K, Ohashi S, Yamakawa M, Miura Y, Tsuda $\mathrm{T}$ : Isolation of bovine arboviruses from Culicoides biting midges (Diptera: Ceratopogonidae) in southern Japan: 1985-2002. J Med Entomol 2005, 42(1):63-67.

35. Mellor PS, Osborne R, Jennings DM: Isolation of bluetongue and related viruses from Culicoides spp. in the Sudan. J Hyg (Lond) 1984, 93(3):621-628.

36. Venter GJ, Mellor PS, Paweska JT: Oral susceptibility of South African stock-associated Culicoides species to bluetongue virus. Med Vet Entomol 2006, 20(3):329-334.

37. Meiswinkel R, Gomulski LM, Delecolle JC, Goffredo M, Gasperi G: The taxonomy of Culicoides vector complexes - unfinished business. Vet ltal 2004, 40(3):151-159.

38. Venter GJ, Paweska JT, Van Dijk AA, Mellor PS, Tabachnick WJ: Vector competence of Culicoides bolitinos and C. imicola for South African 
bluetongue virus serotypes 1, 3 and 4. Med Vet Entomol 1998, 12(4):378-385

39. Venter GJ, Graham SD, Hamblin C: African horse sickness epidemiology: vector competence of south african Culicoides species for virus serotypes 3, 5 and 8. Med Vet Entomol 2000, 14(3):245-250

40. Venter GJ, Groenewald D, Venter E, Hermanides KG, Howell PG: A comparison of the vector competence of the biting midges, Culicoides (Avaritia) bolitinos and C. (A.) imicola, for the Bryanston serotype of equine encephalosis virus. Med Vet Entomol 2002, 16(4):372-377.

41. Venter GJ, Groenewald DM, Paweska JT, Venter EH, Howell PG: Vector competence of selected South African Culicoides species for the Bryanston serotype of equine encephalosis virus. Med Vet Entomol 1999, 13(4):393-400.

42. Paweska JT, Venter GJ, Hamblin C: A comparison of the susceptibility of Culicoides imicola and C. bolitinos to oral infection with eight serotypes of epizootic haemorrhagic disease virus. Med Vet Entomol 2005, 19(2):200-207.

43. Meiswinkel R, Paweska JT: Evidence for a new field Culicoides vector of African horse sickness in South Africa. Prev Vet Med 2003, 60(3):243-253.

44. Lee $\mathrm{VH}$ : Isolation of viruses from field populations of Culicoides (Diptera: Ceratopogonidae) in Nigeria. J Med Entomol 1979, 16(1):76-79.

45. Venter GJ, Koekemoer JJ, Paweska JT: Investigations on outbreaks of African horse sickness in the surveillance zone in South Africa. Rev Sci Tech 2006, 25(3):1097-1109.

46. Venter GJ, Mellor PS, Wright I, Paweska JT: Replication of live-attenuated vaccine strains of bluetongue virus in orally infected South African Culicoides species. Med Vet Entomol 2007, 21(3):239-247.

47. Venter GJ, Paweska JT: Virus recovery rates for wild-type and liveattenuated vaccine strains of African horse sickness virus serotype 7 in orally infected South African Culicoides species. Med Vet Entomol 2007, 21(4):377-383.

48. Venter GJ, Majatladi DM, Labuschagne K, Boikanyo SN, Morey L: The attraction range of the Onderstepoort $220 \mathrm{~V}$ light trap for Culicoides biting midges as determined under South African field conditions. Vet Parasitol 2012, 190(1-2):222-229.

49. Nevill EM: The use of cattle to protect sheep from bluetongue infection. J SAfrVetAssoc 1978, 49(2):129-130.

50. Venter GJ, Meiswinkel R, Nevill EM, Edwardes M: Culicoides (Diptera: (eratopogonidae) associated with livestock in the Onderstepoort area, Gauteng, South Africa as determined by light-trap collections. Onderstepoort J Vet Res 1996, 63(4):315-325.

51. Herniman KA, Boorman JP, Taylor WP: Bluetongue virus in a Nigerian dairy cattle herd. 1. Serological studies and correlation of virus activity to vector population. J Hyg (Lond) 1983, 90(2):177-193.

52. Mushi EZ, Isa JF, Chabo RG, Binta MG, Kapaata RW: Culicoides (Diptera: Ceratopogonidae) associated with horses at Mogoditshane, Gaborone, Botswana. Vet Res Commun 1998, 22(5):295-297.

53. Musuka GN, Meiswinkel R, Baylis M, Kelly PJ, Mellor PS: Prevalence of Culicoides imicola and other species (Diptera: Ceratopogonidae) at eight sites in Zimbabwe. J S Afr Vet Assoc 2001, 72(2):62-63.

54. Harrup LE, Purse BV, Golding N, Mellor PS, Carpenter S: Larval development and emergence sites of farm-associated Culicoides in the United Kingdom. Med Vet Entomol 2013, 27(4):441-449.

55. Poddar TK, Ray S, Choudhury A: Ecology of larval Culicoides oxystoma (Diptera: Ceratopogonidae) in the Hooghly estuary, Sagar Island India. Ann Entomol 1992, 10(1):19-25.

56. Garcia-Saenz A, McCarter P, Baylis M: The influence of host number on the attraction of biting midges, Culicoides spp., to light traps. Med Vet Entomol 2010, 25(1):113-115.

57. Kluiters G, Sugden D, Guis H, Mclntyre KM, Labuschagne K, Vilar MJ, Baylis M: Modelling the spatial distribution of Culicoides biting midges at the local scale. J App/ Ecol 2013, 50(1):232-242.

58. Carpenter S, Szmaragd C, Barber J, Labuschagne K, Gubbins S, Mellor P: An assessment of Culicoides surveillance techniques in northern Europe: have we underestimated a potential bluetongue virus vector? J Appl Ecol 2008, 45(4):1237-1245.

59. Scheffer EG, Venter GJ, Labuschagne K, Page PC, Mullens BA, MacLachlan NJ, Osterrieder N, Guthrie AJ: Comparison of two trapping methods for Culicoides biting midges and determination of African horse sickness virus prevalence in midge populations at Onderstepoort, South Africa. Vet Parasitol 2012, 185(2-4):265-273.

60. Viennet E, Garros C, Lancelot R, Allene X, Gardes L, Rakotoarivony I, Crochet D, Delecolle JC, Moulia C, Baldet T, Balenghien T: Assessment of vector/ host contact: comparison of animal-baited traps and UV-light/suction trap for collecting Culicoides biting midges (Diptera: Ceratopogonidae), vectors of Orbiviruses. Parasit Vectors 2011, 4:119.

doi:10.1186/1756-3305-7-147

Cite this article as: Diarra et al:: Seasonal dynamics of Culicoides (Diptera: Ceratopogonidae) biting midges, potential vectors of African horse sickness and bluetongue viruses in the Niayes area of Senegal. Parasites \& Vectors 2014 7:147

\section{Submit your next manuscript to BioMed Central and take full advantage of:}

- Convenient online submission

- Thorough peer review

- No space constraints or color figure charges

- Immediate publication on acceptance

- Inclusion in PubMed, CAS, Scopus and Google Scholar

- Research which is freely available for redistribution 